\title{
Spotted hyaena space use in relation to human infrastructure inside a protected area
}

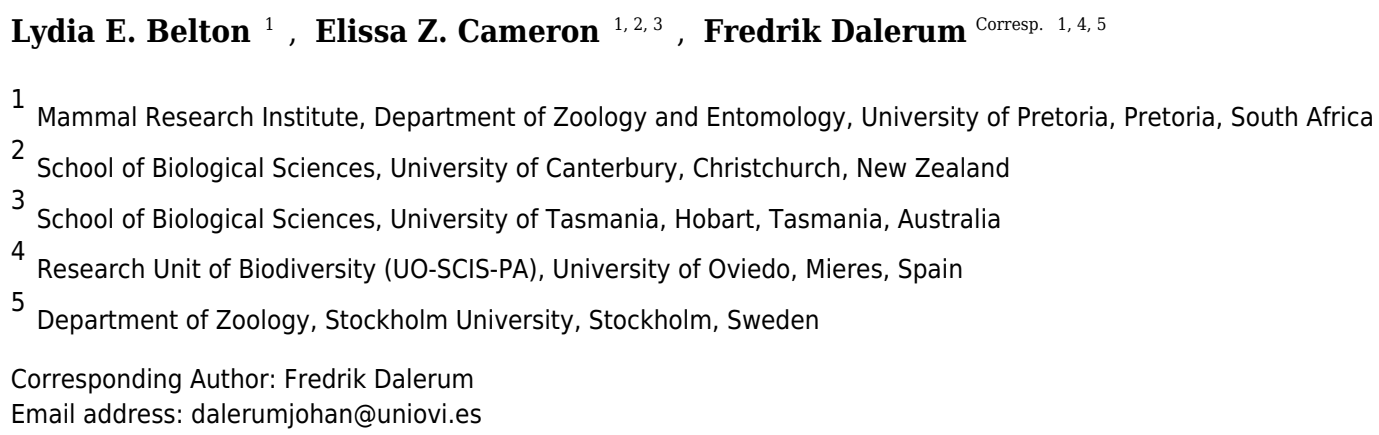

Increasing human population growth has led to elevated levels of human-carnivore conflict. However, some carnivore populations have adapted to urban environments and the resources they supply. Such associations may influence carnivore ecology, behaviour and life-history. Pockets of urbanisation sometimes occur within protected areas, so that anthropogenic influences on carnivore biology are not necessarily confined to unprotected areas. In this study we evaluated associations between human infrastructure and related activity and space use of spotted hyaenas within one of the largest protected areas in South Africa, the Kruger National Park. Home range size was smaller for the dominant female of a clan living in close proximity to humans than that of the dominant female of a clan without direct access to human infrastructure. The home range including human infrastructure was also used less evenly during the night, presumably when the animals were active. Within this home range, the village area was preferred during the night, when the least modified areas within the village were preferred and administration and highly modified areas were avoided. During the day, however, there were no preference or avoidance of the village area, but all habitats except unmodified habitats within the village area were avoided. We suggest that human infrastructure and associated activity influenced hyaena space use, primarily through alterations in the spatial distribution of food. However, these effects may have been indirectly caused by habitat modification that generated favourable hunting habitat rather than a direct effect caused by access to human food such as garbage. Because of the often pivotal effects of apex predators in terrestrial ecosystems, we encourage further work aimed to quantify how human presence influences large carnivores and associated ecosystem processes within protected areas. 
1 Spotted hyaena space use in relation to human infrastructure inside a 2 protected area

$4 \quad$ Lydia E. Belton ${ }^{1}$, Elissa Z. Cameron ${ }^{1,2,3}$, Fredrik Dalerum ${ }^{1,4,5, *}$

61 Mammal Research Institute, Department of Zoology and Entomology, University of

$7 \quad$ Pretoria, Pretoria, South Africa

82 School of Biological Sciences, University of Tasmania, Hobart, Australia

93 School of Biological Sciences, University of Canterbury, Christchurch, New Zealand

104 Research Unit of Biodiversity (UO-CSIC-PA), University of Oviedo, Mieres Campus, 33600 Mieres, Spain

5 Department of Zoology, Stockholm University, 106 91, Stockholm, Sweden 


\section{Manuscript to be reviewed}

\section{ABSTRACT}

Increasing human population growth has led to elevated levels of human-carnivore conflict. However, some carnivore populations have adapted to urban environments and the resources they supply. Such associations may influence carnivore ecology, behaviour and life-history. Pockets of urbanisation sometimes occur within protected areas, so that anthropogenic influences on carnivore biology are not necessarily confined to unprotected areas. In this study we evaluated associations between human infrastructure and related activity and space use of spotted hyaenas within one of the largest protected areas in South Africa, the Kruger National Park. Home range size was smaller for the dominant female of a clan living in close proximity to humans than that of the dominant female of a clan without direct access to human infrastructure. The home range including human infrastructure was also used less evenly during the night, presumably when the animals were active. Within this home range, the village area was preferred during the night, when the least modified areas within the village were preferred and administration and highly modified areas were avoided. During the day, however, there were no preference or avoidance of the village area, but all habitats except unmodified habitats within the village area were avoided. We suggest that human infrastructure and associated activity influenced hyaena space use, primarily through alterations in the spatial distribution of food. However, these effects may have been indirectly caused by habitat modification that generated favourable hunting habitat rather than a direct effect caused by access to human food such as garbage. Because of the often pivotal effects of apex predators in terrestrial ecosystems, we encourage further work aimed to quantify how human presence influences large carnivores and associated ecosystem processes within protected areas. 


\section{Manuscript to be reviewed}

\section{INTRODUCTION}

Human population growth is bringing people into conflict with carnivores at higher frequencies than ever before (Woodroffe, 2000). Carnivores are considered particularly sensitive to human population growth and urbanisation due to persecution, large home range requirements and slow population growth (Cardillo et al., 2004). The rapid expansion of urban landscapes creates both biotic and abiotic changes that negatively impact carnivore populations (Šálek, Drahníková \& Tkadlec, 2015). This can cause local extinctions or active avoidance of humans by carnivores (Ordeñana et al., 2010; Schuette et al., 2013).

However, whilst anthropogenic disturbance is classically known for causing population declines (Woodroffe, 2000), some carnivores have adapted to live in close proximity to humans and may directly benefit from the association (e.g. Fedriani, Fuller \& Sauvajot, 2001; Contesse et al., 2004; Bozek, Prange \& Gehrt, 2007). For carnivores living in close association with humans, several demographic and behavioural changes have been noted, such as alterations in population density (Fedriani, Fuller \& Sauvajot, 2001), home range size (Quinn \& Whisson, 2005), diet (Newsome et al., 2014), and space utilisation (Gilchrist \& Otali, 2002). Such changes are often attributed to anthropogenic food supplementing the diet.

An increase in use of anthropogenic food has frequently been associated with a contraction in home range and core area size (Kolowski \& Holekamp, 2008; Newsome et al., 2014; Šálek, Drahníková \& Tkadlec, 2015). However, home range size and use is also dependent on other factors, such as seasonal variation in native food sources. Typically, the season with a lower abundance of native food has coincided with more frequent anthropogenic food use (Lucherini \& Crema, 1994; Kolowski \& Holekamp, 2008; Pereira, Owen-Smith \& Moleón, 2013). In addition, behavioural and physiological differences related to sex (Beckmann \& Berger, 2003) and social status (Boydston et al., 2003) may also 
influence space use and resource exploitation.

Most research on anthropogenic influences on carnivore biology has been conducted in urban environments (reviewed in Bateman \& Fleming, 2012). However, areas of elevated human activity also occur inside protected areas (e.g. Gilchrist \& Otali, 2002; Quinn \& Whisson, 2005), and many anthropogenic factors influencing carnivore space use may also exist inside protected areas. Despite the obvious management implications of the influence of human activities on carnivore space use inside protected areas, studies on anthropogenic influences on carnivores within protected areas is scarce compared to data focusing on urban and suburban landscapes.

The spotted hyaena (Crocuta crocuta) is a large, primarily nocturnal carnivore that lives in social groups (clans) with fission-fusion social dynamics, meaning that clan members are not always spatially co-located at all times. A clan consists of related females and their offspring as well as unrelated adult males (Kruuk, 1972; Mills, 1984; Henschel, 1986).Within a clan the hyaenas are organized by a strict social hierarchy where females are dominant to adult males, and ranks are temporally consistent (Kruuk 1972).The range of the spotted hyaena covers much of sub-Saharan Africa, from the Kalahari Desert (Mills, 1984) to periurban areas in Ethiopia (Abay et al., 2010), although distribution is patchy (IUCN, 2015). The spotted hyaena is known for its opportunistic scavenging (Mills \& Hofer, 1998), and the species will readily exploit anthropogenic food (Yirga et al., 2015). In contrast to many species associated with anthropogenic food use, spotted hyaenas are large carnivores that often hunt large prey (Cooper, Holekamp \& Smale, 1999). However, their food is often seasonally variable, a trait associated with anthropogenic food use in other species. In southern Africa, the wet season is typically associated with increased prey availability related to the reproduction of prey species (Pereira, Owen-Smith \& Moleón, 2013), while the dry season in contrast is associated with drought and elevated animal mortality partially caused by 
disease (Owen-Smith, 1990; Pereira, Owen-Smith \& Moleón, 2013). Hence, environmental factors could influence anthropogenic resource use in this species.

To date, there is very scant information on the effects of anthropogenic resources on spotted hyaena space use, and all accounts we are aware of come from east Africa (Kolowski \& Holekamp, 2008; Yirga et al. 2015). For instance, a single source of anthropogenic food associated with a small human settlement had a marked impact on hyaena space use patterns in the Masai Mara National Reserve in Kenya (Kolowski \& Holekamp, 2008). Here, we aimed to test if a larger but less concentrated source of anthropogenic resources would have a similar influence on hyaena space use patterns. We monitored the space use of two spotted hyaena females belonging to separate clans inside the Kruger National Park (KNP), South Africa, one inhabiting an area with high levels of permanent human activity and extensive and complex infrastructure. Hence, this clan had direct access to anthropogenic resources, although those resources were spread out spatially rather than located at a single source. The other clan inhabited an area with very limited human activity and almost no permanent infrastructure. The hyaenas in this clan therefore relied almost entirely on native resources.

Because the often clustered distribution of human resources frequently cause carnivore range contraction (Šálek, Drahníková \& Tkadlec, 2015), an observation that is related to the general importance of the distribution of critical resources for carnivore space use (Sandell, 1989), we predicted that hyaenas living in an environment with high levels of human resources would have a smaller home range and use it less evenly than hyaenas living without direct access to anthropogenic resources. We also predicted that human influence on space use would be higher in the food limited dry season compared to the wet season. In addition, human infrastructure and associated activity may simultaneously present sites of high resource availability but also of potential disturbance. Extensive human settlements may be beneficial in that that they provide more resources which are reliably available, yet they often 
represent sites that have higher rates of disturbance and potential risks. We therefore predicted that hyaenas would use areas close to human residential infrastructure in relation to the relative trade-off between the resource value and the cost of disturbance. Such trade-offs could lead to temporal avoidance or preference of areas with human infrastructure, where the use of anthropogenic resources is higher during periods of low levels of human activity.

\section{MATERIALS AND METHODS}

\section{Study Area}

The KNP is situated in the north eastern corner of South Africa and covers almost two million hectares (Fig. 1). This study took place between May 2007 and March 2010 in a $5000 \mathrm{~km}^{2}$ southern portion of the park. Vegetation in the study area is characterised by woodland with basalt soils dominated by Clerocarya caffra and Acacia nigrescens, with Combretum species on granite soils (Ogutu \& Owen-Smith, 2003). Rainfall is seasonal with the majority falling between October and March, with a peak in January and February (Venter, Scholes \& Eckhardt, 2003). Average annual rainfall is approximately $650 \mathrm{~mm}$ for the Southern section (Venter \& Gertenbach, 1986). Mean monthly temperatures range from 7 to $32^{\circ} \mathrm{C}$ for this area (Venter \& Gertenbach, 1986). KNP hosts a diverse array of herbivorous and carnivorous mammals. Prey available for hyaenas in the Southern section of the park include, along with small mammals; impala (Aepyceros melampus), blue wildebeest (Connochaetes taurinus), Burchell's zebra (Equus burchelli), greater kudu (Tragelaphus strepsiceros), common warthog (Phacochoerus africanus), imbabala bushbuck (Tragelaphus sylvaticus), nyala (Nyala angasii), common reedbuck (Redunca arundinum), waterbuck (Kobus ellipsiprymnus), steenbok (Raphicerus campestris), common duiker (Sylvicapra grimmia) and Cape buffalo (Syncerus caffer). Other megaherbivores such as African elephant (Loxodonta africana), white rhinoceros (Ceratotherium simum), black rhinoceros (Diceros bicornis), and giraffe 
137 (Giraffa camelopardalis) are also available, presumably most often as carrion. Impala in particular constitutes a large part of the hyaena diet in KNP (Henschel \& Skinner, 1990; Ryan, 2007). Four large carnivores live sympatrically with hyaenas in KNP; African lion (Panthera leo), leopard (Panthera pardus), cheetah (Acinonyx jubatus), and African wild dog (Lycaon pictus).

Data were collected in two areas with contrasting levels of human activity. The Skukuza area included the Skukuza rest camp and staff village area ( $\left.31^{\circ} 59^{\prime} \mathrm{E}, 2^{\circ} 00^{\prime} \mathrm{S}\right)$. Skukuza is the largest rest camp in KNP and hosts up to 300 visitors. It is also the administrative hub for the whole of KNP with a large staff village. In Skukuza, hyaenas had free access to the unfenced staff village consisting of 250 houses, an enclosed staff compound, a golf course, a shop, communal areas, and administrative buildings beside an enclosed area with tourist accommodation (rest camp). The staff area combined with the rest camp covers $4.3 \mathrm{~km}^{2}$ and houses approximately 2300 staff (Foxcroft, Richardson \& Wilson, 2008). Fences around both individual houses and the compound prevented easy access to household rubbish bins. However rubbish bins in communal areas and larger waste collection sites were unfenced. Open gates and damaged fencing also allowed for opportunistic access to other rubbish bins. Hyaenas also had access to the unfenced car park of a picnic site, which contained rubbish bins and they were able to walk along the perimeter fence of the tourist rest camp. Visitors are required to return to a camp or leave the park by a specific time that varies throughout the year to coincide with sunset and members of staff do not walk in unfenced areas after dark. Animals were therefore able to use unfenced anthropogenic areas after dark with minimal disturbance. In contrast, we also collected data in a neighbouring area (Doispane; $31^{\circ} 25^{\prime} \mathrm{E}$, $25^{\circ} 01^{\prime} \mathrm{S}$ ) approximately $20 \mathrm{~km}$ away that had limited levels of human activity and the only permanent infrastructure was a building that occasionally was used for short stays by park staff or guests. The Doispane area was at the border of the park and had similar to the 
Skukuza area access to permanent water. Vegetation in this region of the Kruger National Park is homogeneous (Rutherford et al., 2006). Water access, which is one of the main drivers behind herbivore distribution within the park (Redfern et al., 2003; Smit et al., 2007), was similar between the two areas and prey densities are relatively homogeneous throughout this southern section of the Kruger National Park (Seydack et al., 2012). Therefore, the main differences between the two areas in terms of resource availability for spotted hyaenas are likely related to the elevated human presence in Skukuza caused by the Skukuza village complex.

\section{Study animals and instrumentation}

Each area (e.g., Skukuza and Doispane) was inhabited by one spotted hyaena clan. The clan in Skukuza consisted of 5 adult females, 1 adult male and up to 9 subadult or young adult males and 7 subadult or young adult females. The Doispane clan was substantially smaller and consisted of 3 adult females, 2 adult males and up to 2 subadult or young adult males and 1 subadult or young adult female. Both clans had juveniles present during the duration of the time they were monitored. We monitored the clan in Skukuza from May 2007 to December 2009 and the one at Doispane from May 2007 until August 2008. Monitoring was primarily done at the den locations but also when animals were opportunistically encountered. Observations were partly done for a concurrent study on the influence of human activity on hyaena behaviour and ecology. We monitored the locations of den sites throughout the study by visiting the clans. These visits varied in frequency from daily to once every second week. When a den was not located within sight of a road, we used clusters of relocations from marked animals (see below) at dawn and dusk to identified likely den locations, which were confirmed by direct visitations. In each clan we had all animals individually recognized based on general characteristics and spot patterns. We scored rank relationships from the outcome of 


\section{Manuscript to be reviewed}

187 pair-wise interactions.

188

We fitted one animal in each clan with a collar mounted GPS unit that was tasked to download data through the GSM network (African Wildlife Tracking, Pretoria, South Africa). We selected the dominant female from each clan to create a reliable comparison (Boydston et al., 2003). The social rank was confirmed through behavioural observations of aggressive interactions between clan members. The animals were immobilised from a vehicle by a veterinarian from South Africa National Parks' Veterinary Wildlife Service department. Both animals were first baited with three pieces of meat, each containing 2 x 15 mg midazolam tablets to enable safer darting. A combination of $4 \mathrm{mg}$ medetomidine hydrochloride and $60 \mathrm{mg}$ Zoletil was then delivered via a $\mathrm{CO}_{2}$-powered dart rifle. An intramuscular injection of atipamezole was administered to reverse the effects of the medetomidine and animals were kept under observation whilst recovering. The female in Skukuza was fitted with her first collar on the $20^{\text {th }}$ October 2007 . This stopped working $5^{\text {th }}$ July 2008 and was replaced $24^{\text {th }}$ April 2009. The second collar stopped working on the $19^{\text {th }}$ November 2009 and could not be removed. The collar on the female in Doispane was fitted on the $20^{\text {th }}$ November 2007 and removed July 2011, although we only had access to data from this collar until 6 March 2010. We therefore collected spatial data on the female in Skukuza during the periods October 2007 - 5 July 2008 and 24 April - 19 November 2009 and on the female in Doispane during the period 20 November 2007 - 6 March 2010. Hence, we collected data on both clans simultaneously for the majority of the time the Skukuza clan had an active collar, and we additionally collected data on an extended time period for the Doispane clan. Although sample size may bias home range size estimates, we have retained our full data record in the analyses to improve the accuracy of the estimated home ranges for Doispane. With the complete set of locations we had sufficient samples sizes in both Skukuza and Doispane to accurately estimate seasonal home range sizes (Supplementary Information 1), so that the 
uneven sample sizes should not influence any differences between the clans in terms of home range size. Both females were nursing during the time for which each clan were observed, i.e. May 2007 to December 2009 for Skukuza and May 2007 to August 2008 for Doispane. hyaenas".

\section{Data collection, classification and analyses}

The collars were set to take readings on an 11 hour schedule. This schedule provided temporally independent points that covered all hours of the day. Each relocation point was classed as night, day or den. We regarded the time between one hour before sunset and one hour after sunrise as night time and times outside of these hours as day time as it correspond to spotted hyaena activity patterns (Henschel, 1986; Kolowski et al., 2007). Although we acknowledge that we did not have direct measurement of activity during each of these time periods, our observations confirmed that activity within both clans were principally nocturnal, suggesting that most locations during the night were of active animals and locations during the day were resting locations. Data on sunrise and sunset times for the local area were retrieved from a weather service internet site (http://www.timeanddate.com). However, any relocation that occurred within $30 \mathrm{~m}$ of an identified den site was labelled as den points regardless of the time of day. In addition to these three classes of locations, we also grouped

236 having occurred during the dry season. 
We used 95\% Minimum Convex Polygons (MCP's: Mohr, 1947) to estimate home range sizes for each animal. We used MCP's to quantify home range sizes because they are relatively robust to possible temporal autocorrelation among data and they do not rely on arbitrarily chosen smoothing parameters or spatial resolutions of the underlying reference grid, which could influence the resulting space use estimates (Swihart \& Slade, 1985; Row \& Blouin-Demers, 2006; Boyle et al., 2009). MCP estimates are also repeatable across different software programs and therefore provide results that are directly comparable with those of other studies (Harris et al., 1990; Larkin \& Halkin, 1994; Lawson \& Rodgers, 1997). During October 2008, the clan at Doispane shifted its home range to the west with only a small overlap with the previous home-range. This shift included a shift in den locations, and our observations confirmed that all clan members appear to have shifted their movement patterns along with the marked female. We have therefore treated these two areas as separate home ranges for our analyses. Due to their highly clustered nature, we removed den site locations from all home range size estimations, but we have included them in the visual representation of the home ranges because den location potentially can influence home range patterns. For each home range, we created three size estimates, one including all relocations, one for the wet season and one for the dry season. We based our home range estimates on 745 locations (470 in the dry and 275 in the wet season) for the Skukuza female, 269 locations (138 dry and 131 wet season) for the Doispane female in the initial home range and 558 (195 dry and 363 wet season) locations in the subsequent home range.

We used two metrics to evaluate the spatial patterns of utilization within each home range. First, we quantified the utilization of the home ranges during the night, i.e. when we regarded the animals to have been active, using a normalized Shannon spatial diversity index (Payne et al., 2005). This index provides a measure of the evenness of home range utilization and varies from 0 , which indicates a completely clustered utilization, to 1 , which indicates a 
completely even utilization of the home range. The index is a quantification of continuous use of space, albeit sampled at discrete points in time. We selected this index for the night time locations because we regard them to be instantaneous point samples of a continuous movement process, and hence this index to be more appropriate than indices that explicitly evaluate patterns of discrete spatial points. To calculate this index, we first created a grid where the cells corresponded to $1 \%$ of respective home range, and calculated the number of relocations within each cell. The grid was confined within each respective estimated home as:

$$
H^{\prime}=\frac{\sum_{i=1}^{N} P_{i} x \ln \left(P_{i}\right)}{\ln (N)}
$$

where $N$ is the total number of cells in each home range and $P_{i}$ is the proportion of relocations in each given cell $i$. We calculated indices for all relocations combined as well as one index for each season. Second, we used the nearest neighbour index to quantify the spatial distributions of day time locations, i.e. when we regarded animals to have been resting (Clarke \& Evans 1954). We opted for a separate index for the day time locations because it is explicitly quantifying the spatial distribution of discrete spatial events, which we believe was appropriate for the distribution of locations when animals were assumed to have been stationary. The nearest neighbour index $(R)$ ranges from 0 (totally clustered distribution) to 2.15 (completely even distribution), and is scaled so that a value of 1 indicates a random distribution, values $>1$ indicates an over-dispersed distribution and values $<1$ indicates a clustered distribution. For both indices, we evaluated if the observed values deviated from 
expectations based on a random spatial distribution of points by generating 1000 random point data sets for each home range, each constrained within the home range border and with the same number of locations as the real datasets, and then calculated the index values for each of these random data sets. A random utilization is a sensible expectation to have under the null hypothesis of no preference for features or areas within a home range (Samuel, Pierce \& Garton 1985). We evaluated how likely the observed index values were under random expectations using a z-score transformation based on values from the randomly generated data (Baddeley, Rubak \& Turner 2015). As a heuristic way of comparing the spatial distribution of night and day time locations between the Skukuza and the Doispane clans, we subtracted the observed value from those calculated from the random data sets (Manly 1997), and used these deviations from random expectations to compare the Shannon and nearest neighbour index between the Skukuza and each of the Doispane home ranges using two-sample permutation tests. We did one comparison for each pair of home ranges (i.e. Skukuza and each of the two Doispane ranges) for both seasons combined as well as one for each season.

We evaluated the utilization of the urban village area in Skukuza at two separate scales. First, we outlined the whole village area using satellite images retrieved from Google Earth (www.google.com/earth/), supplemented with GPS data collected in the field. We quantified the number of night time (i.e. active) and day time (resting) locations within and outside this area. Second, we described the utilization of different land use types within the village area. For this quantification, we similarly created a map that delineated four different types of land use in the area; highly modified areas - unfenced area with high levels of human use that are unfenced, administration areas - unfenced areas containing business buildings and their surrounding car parks with no fences, intermediately modified areas - areas that have been altered from their natural state but are without buildings or facilities, e.g. golf course and a cricket pitch, and unmodified areas - unaltered habitat inside the village boundary. We then 
scored each location in the village area to belong to each of these four classes. For both scales, we used a simple resource selection function to determine whether areas were preferred or avoided during night and day, i.e. while active or resting. Following Manly et al. (1993), we calculated the selection indices $\beta_{i}$ as:

$$
B_{i}=\frac{w_{i}}{\sum_{i=1}^{H} w_{i}}
$$

where $w_{i}$ is the selection ratios for each land use class $i$ (i.e. the proportion of locations within each class divided by the proportion of available land that each class was covering) and $H$ is the total number of land use classes. For ease of interpretation, we scaled each index so that a value of zero indicates that a class has been used in relation to its availability, a negative value suggests avoidance and a positive value suggests selection (Dalerum, Boutin \& Dunford, 2007). We evaluated whether the utilization of the different habitat classes (i.e. within or outside of the village area or the four land use types within the village area) deviated significantly from a utilization based on availability using chi-square tests.

\section{RESULTS}

Home range sizes varied both seasonally as well as between the two females. Despite being part of a larger clan, the female in Skukuza had a smaller home range than the Doispane one both annually as well as within each season (Table 1). The home ranges were not utilized evenly, and all home ranges were less evenly used by night and had more clustered patterns of daytime locations than expected by random distributions (Table 2). The Skukuza female had a different spatial distribution of locations during the night compared to the Doispane female, for both seasons combined (Skukuza vs. Doispane a, $\mathrm{Z}=43.8, \mathrm{p}<0.001$, Skukuza vs. 
Doispane b, $\mathrm{Z}=44.1, \mathrm{p}<0.001$ ), for the dry season (Skukuza vs. Doispane a, $\mathrm{Z}=13.1, \mathrm{p}<$

0.001, Skukuza vs. Doispane b, $\mathrm{Z}=43.2, \mathrm{p}<0.001$ ), and for the wet season (Skukuza vs.

Doispane a, $\mathrm{Z}=43.4, \mathrm{p}<0.001$, Skukuza vs. Doispane $\mathrm{b}, \mathrm{Z}=41.2, \mathrm{p}<0.001$ ). Although the Skukuza female utilized its home range more evenly than the utilization in the second Doispane range on an annual basis, it utilized its home range less evenly than both Doispane ranges within each season (Table 2). Similarly, the distribution of day time locations differed between the Skukuza and the Doispane females (both seasons combined: Skukuza vs.

Doispane a, $\mathrm{Z}=6.69, \mathrm{p}<0.001$, Skukuza vs. Doispane b, $\mathrm{Z}=13.2, \mathrm{p}<0.001$; Dry season: Skukuza vs. Doispane a, $Z=32.2, p<0.001$, Skukuza vs. Doispane b, $Z=15.1, p<0.001$; Wet season: Skukuza vs. Doispane b, $\mathrm{Z}=33.0, \mathrm{p}<0.001$ ), with the exception of differences between Skukuza and the second Doispane home range during the wet season $(\mathrm{Z}<0.01, \mathrm{p}=$ 0.998). The day time points in the Skukuza home range were more clustered than both Doispane ranges for both seasons combined as well as for the dry season, but were more clustered than only one of the two Doispane home ranges during the wet season (Table 2). For the Skukuza female, more locations during the night were found inside the village area than what could be expected based on its proportion within the home range (Table 3), for both seasons combined $\left(\chi^{2}=67.4, \mathrm{df}=1, \mathrm{p}<0.001\right)$ as well as for both the dry $\left(\chi^{2}=21.9\right.$, $\mathrm{df}$ $=1, \mathrm{p}<0.001)$ and the wet season $\left(\chi^{2}=50.7, \mathrm{df}=1, \mathrm{p}<0.001\right)$. Within the village area, the utilization of the different land use types also differed from their availability (both seasons combined $\chi^{2}=86.3$, df $=1, \mathrm{p}<0.001$; dry season $\chi^{2}=48.4$, df $=1, \mathrm{p}<0.001$; wet season $\chi^{2}=$ 47.6, $\mathrm{df}=1, \mathrm{p}<0.001$ ), with the intermediately modified and unmodified areas being preferred and the highly modified and administration areas avoided (Table 3). During the day, the village area was neither preferred nor avoided (Table 3; both seasons combined $\chi^{2}=0.59$, $\mathrm{df}=1, \mathrm{p}=0.443$; dry season $\chi^{2}=3.44, \mathrm{df}=1, \mathrm{p}=0.063$; wet season $\chi^{2}=0.48, \mathrm{df}=1, \mathrm{p}=$ 0.488). Within the village area, however, unmodified habitat was generally being preferred 
during the day (both seasons combined $\chi^{2}=17.9$, $\mathrm{df}=3, \mathrm{p}<0.001$; dry season $\chi^{2}=7.27$, $\mathrm{df}=$ 3, $\mathrm{p}<0.063$; wet season $\chi^{2}=8.88, \mathrm{df}=3, \mathrm{p}=0.031$, Table 3).

\section{DISCUSSION}

Annual and seasonal home range sizes for the Skukuza female were consistently smaller than both of the Doispane female's home ranges. These observations suggest that human activity and infrastructure were associated with spotted hyaena home range sizes according to our first prediction, i.e. that human infrastructure and activity would be associated with smaller home ranges. Such an interpretation of our results would agree with previous studies that have highlighted that access to anthropogenic areas may reduce carnivore home range sizes (e.g., Šálek, Drahníková \& Tkadlec, 2015). Increased availability of resources may reduce home range sizes, especially for larger carnivores that often need to use large areas in search of prey (Kolowski \& Holekamp, 2008; Gerht \& Riley, 2010; Newsome et al., 2013). Our comparison included two females of equal rank that inhabited areas of similar habitat with comparable prey densities, and therefore we suggest that human infrastructure and activity were associated with spotted hyaena space use by altering resource distributions. We highlight that this interpretation is further supported both by the differences in clan sizes and in number of re-locations for each seasonal home range. The clan with the larger size would be predicted to have a larger home range because of an increased metabolic need (Gittleman \& Harvey, 1982), and any potential sample size effect would cause a positive relation between number of re-locations and estimated home range size (Boyle et al., 2009). Instead, we observed the opposite, the clan with the smallest home range was both the largest and had the most number of relocations for home range estimation. We interpret these observations as further support for an association between human activity and infrastructure and the observed home range sizes. 
In addition, the Skukuza female utilized its home range less evenly than the Doispane one, which emphasizes that human infrastructure and related activity may not only have been associated with total home range sizes, but also with how hyaenas used space within these areas. Space use was aggregated during both night and day time, which agrees with previous observations of spotted hyaenas (Henschel, 1986; Boydston et al., 2003). For both seasons the Skuzuza female used its home range less evenly than the Doispane one. Patchy resource distributions have often led to uneven space use (Macdonald, 1983; Gilchrist \& Otali, 2002). We therefore suggest that the less even space use in Skukuza supported our second prediction, i.e. that spatially concentrated resources associated with the village area would cause a less even home range utilization. Although the day time locations, presumably when animals were resting, similarly were more clustered than random expectations, day time locations in Skukuza were more clustered than only one of the Doispane home ranges, but not the other. This supports an interpretation where resources associated with anthropogenic food influenced spotted hyaena space use, because food distribution should have little influence on the locations where hyaenas spend their resting hours. However, we note that there was only marginal seasonal variation in the differences between clans in terms of home range size and use. This observation contradicts our third prediction, and instead suggests that temporal variation in native food did not alter the association between anthropogenic areas and spotted hyaena space use.

In agreement with other studies (Quinn \& Whisson, 2005; e.g. Bozek, Prange \& Gehrt, 2007), the Skukuza female showed a preference for the village area during the night, i.e. presumably when active. Within the village area, hyaenas preferred intermediately modified habitat the most, followed by unmodified habitat. Administrative and high impact areas were both avoided during the night. The intermediately modified habitat primarily consisted of open areas such as a golf course, a cricket pitch and various patches of disturbed 
410 but un-built land. Contrarily, there was no significant preference for or avoidance of the

411 village area during the day, and within the village area all other habitat classes but the

412 undisturbed habitat were avoided. We suggest that these observations supported also our final

413 prediction, that resources would be utilized according to a trade-off between potential benefits

414 and expected risks. Although we do not have information on direct access to anthropogenic

415 resources, such resources would have been more available in the highly modified areas which

416 were consistently selected against. The unmodified and particularly the intermediately

417 modified habitat instead presented artificial open habitat patches. In particular, the golf course

418 attracted several prey species such as impala and warthog because of its artificially watered

419 vegetation. We believe that this could have generated a habitat patch with aggregations of

420 native prey that additionally was more favourable for hunting than the surrounding

421 woodlands (Mills \& Funston, 2003). We therefore suggest that the village area may not have

422 been utilized to gain direct access to anthropogenic resources, but that the preference for the

423 village area was driven by an indirect access to aggregations of native prey that existed in

424 favourable hunting habitat. Such an interpretation is further supported by the lack of habitat

425 preferences for any but the unmodified habitat during resting hours, because areas close to

426 infrastructure that may represent elevated human activity probably were avoided if they were

427 not associated to direct or indirect benefits (e.g. Gerht \& Riley, 2010; Riley et al., 2010).

We acknowledge several shortcomings with our study. Our study is preliminary because we have an effective sample size of only one clan. This limits broader conclusions of our results, but none the less provides some insights into further directions for research. Additionally, we compared two clans over somewhat different time periods. This could have biased the results in four principal ways. First, because sample size is related to estimated 
for each clan. However, it appears that we had reached an asymptote for all seasonal ranges.

Additionally, we had lower sample sizes for the home ranges that were estimated to have been the biggest. Hence, any potential effect of sample size should have strengthened rather than weakened our conclusions. Second, because we collected data in Doispane during periods when we did not collect data in Skukuza, environmental conditions could have caused additional biases in the results. We can not rule out that such biases influenced our data. However, environmental conditions are relatively consistent in the study area, and we did monitor both clans simultaneously during the majority of the time. We therefore regard it unlikely that temporal variation in environmental conditions had a large influence on our results. Third, the two groups differed in both group size and composition. However, as group size generally is expected to cause increased home range sizes in group living carnivores, and we observed a negative relationship between group size and home range size, we interpret also this potential bias to strengthen rather than weaken our data interpretation. Finally, we collected data on only a single female in each clan. Although we attempted to minimize potential biases by marking the dominant female, state dependent differences such as pregnancy and lactation may still have influenced our comparison (Boydston et al., 2003). However, when observed, both females were nursing. We interpret these observations that both females had similar reproductive states throughout the study, although we can not confirm this with direct observations.

To conclude, although this study was based on observations on only two individuals within two clans, it provided valuable insights into the effects of anthropogenic areas on the space use of a large carnivore inside a protected area. Our observations supported that human infrastructure and related activity were associated with hyaena space use, and that these associations at least to some extent may have been related to resource supply, but only indirectly by generating favourable hunting areas. We highlight that further work is needed to 
explore associations between humans and large carnivores and their related ecosystem processes within protected areas. In particular, we argue that we need to quantify the relative effects of direct provision of food through anthropogenic resources versus indirect provision of food through the creation of favourable hunting habitats, and if such effects alter large carnivore ecosystem function in protected areas.

\section{Acknowledgements}

We are grateful to Daniel Swanepoel and Mariana Venter for assistance with field observations, to the research office at the South African National Parks board for permission to carry out the study, and and to the Veterinary Wildlife Services in Skukuza for assistance with capturing the hyaenas.

\section{References}

Abay GY., Bauer H., Gebrihiwot K., Deckers J. 2010. Peri-urban spotted hyena (Crocuta crocuta) in Northern Ethiopia: diet, economic impact, and abundance. European Journal of Wildlife Research 57:759-765. DOI: 10.1007/s10344-010-0484-8.

Baddeley A, Rubak E, Turner R. 2015. Spatial point patterns: Methodology and applications with R. London: Chapman and Hall.

Bateman PW., Fleming PA. 2012. Big city life: carnivores in urban environments. Journal of Zoology 287:1-23. DOI: 10.1111/j.1469-7998.2011.00887.x.

Beckmann JP., Berger J. 2003. Rapid ecological and behavioural changes in carnivores: the responses of black bears (Ursus americanus) to altered food. Journal of Zoology 261:207-212. DOI: 10.1017/S0952836903004126.

Boydston EE., Kapheim KM., Szykman M., Holekamp KE. 2003. Individual variation in space use by female spotted hyenas. Journal of Mammalogy 84:1006-1018. DOI: 


\section{Manuscript to be reviewed}

485

486

487

488

489

490

491

492

493

494

495

496

497

498

499

500

501

502

503

504

505

506

507

508

509

10.1644/BOS-038.

Boyle SA., Laurenco WC., da Silva LR., Smith AT. 2009. Home range size vary with sample size and methods. Folia Primatologia 80:33-42. DOI: 101159/000201092.

Bozek CK., Prange S., Gehrt SD. 2007. The influence of anthropogenic resources on multiscale habitat selection by raccoons. Urban Ecosystems 10:413-425. DOI: 10.1007/s11252-007-0033-8.

Cardillo M., Purvis A., Sechrest W., Gittleman JL., Bielby JL., Mace GM. 2004. Human population density and extinction risk in the worlds carnivores. PloS Biology 2:09090914. DOI: 10.1371/journal.pbio.0020197.

Clark PJ., Evans FC. 1954. Distance to nearest neighbor as a measure of spatial relationships in populations. Ecology, 35:445-453. DOI: 10.2307/1931034.

Contesse P., Hegglin D., Gloor S., Bontadina F., Deplazes P. 2004. The diet of urban foxes (Vulpes vulpes) and the availablity of anthropogenic food in the city of Zurich, Switzerland. Mammalian Biology 69:81-95. DOI: 10.1078/1616-5047-00123.

Cooper SM., Holekamp KE., Smale L. 1999. A seasonal feast: long-term analysis of feeding behaviour in the spotted hyaena (Crocuta crocuta). African Journal of Ecology 37:149_ 160. DOI: 10.1046/j.1365-2028.1999.00161.x.

Dalerum F., Boutin S., Dunford JS. 2007. Wildfire effects on home range size and fidelity of boreal caribou in Alberta, Canada. Canadian Journal of Zoology 85:26-32. DOI: 10.1139/z06-186.

Fedriani JM., Fuller TK., Sauvajot RM. 2001. Does availability of anthropogenic food enhance densities of omnivorous mammals? An example with coyotes in southern California. Ecography 24:325-331. DOI: 10.1034/j.1600-0587.2001.240310.x.

Foxcroft LC., Richardson DM., Wilson JRU. 2008. Ornamental plants as invasive aliens: problems and solutions in Kruger National Park, South Africa. Environmental 
Management 41:32-51. DOI: 10.1007/s00267-007-9027-9.

Gerht S., Riley SP. 2010. Coyotes (Canis latrans). In: Gerht S., Riley SP., Cypher BL eds. Urban carnivores: ecology, conflict and conservation. Baltimore: John Hopkins University press, 79-96.

Gilchrist JS., Otali E. 2002. The effects of refuse-feeding on home-range use, group size, and intergroup encounters in the banded mongoose. Canadian Journal of Zoology 80:1795-1802. DOI: 10.1644/BRG-021 491-497.

Gittleman JL., HarveyPH. 1982. Carnivore home-range size, metabolic needs, and ecology. Behavioral Ecology and Sociobiology 10:57-63. DOI:10.1007/BF00296396.

Harris S., Cresswell WJ., Forde PG., Trewhella WJ., Woollard T., Wray S. 1990. Homerange analysis using radio-tracking data-a review of problems and techniques particularly as applied to the study of mammals. Mammal Review 20:97-123. DOI: 10.1111/j.1365-2907.1990.tb00106.x.

Henschel JR. 1986. The socio-ecology of a spotted hyaena (Crocuta crocuta) clan in The Kruger National Park. MSc Thesis. Pretoria: University of Pretoria.

Henschel JR., Skinner JD. 1990. The diet of the spotted hyaenas Crocuta crocuta in Kruger National Park. African Journal of Ecology 28:69-82. DOI: 10.1111/j.13652028.1990.tb01138.x.

IUCN. 2015. The IUCN Red List of Threatened Species. Version 2015.1. <http://www.iucnredlist.org>. Downloaded on 22nd June 2015.

Kolowski JM., Katan D., Theis KR., Holekamp KE. 2007. Daily patterns of activity in the spotted hyena. Journal of Mammalogy 88:1017-1028. DOI: 10.1644/06-MAMM-A143R.1.

Kolowski JM., Holekamp KE. 2008. Effects of an open refuse pit on space use patterns of spotted hyenas. African Journal of Ecology 46:341-349. DOI: 10.1111/j.1365- 


\section{Manuscript to be reviewed}

2028.2007.00846.x.

Kruuk H. 1972. The spotted hyena: a study of predation and social behavior. Chicago: University of Chicago Press.

Larkin RP., Halkin D. 1994. A review of software packages for estimating animal home ranges. Wildlife Society Bulletin (1973-2006) 22:274-287.

Lawson EJG., Rodgers AR. 1997. Differences in home-range size computed in commonly used software programs. Wildlife Society Bulletin (1973-2006) 25:721-729.

Lucherini M., Crema G. 1994. Seasonal variation in diet and trophic niche of the red fox in an alpine habitat. Zeitschrift für Säugetierkunde 59:1-8.

Macdonald DW. 1983. The ecology of carnivore social behaviour. Nature 301:379-384. DOI: $10.1038 / 301379 a 0$.

Manly BFJ. 2007. Randomization, bootstrap, and Monte Carlo methods in biology. 2nd ed. London: Chapman and Hall.

Manly BJF., McDonald L., Thomas D. 1993. Resource selection by animals: statistical design and analysis for field studies. London: Chapman and Hall.

Mills MGL. 1984. The comparative behavioural ecology of the brown hyaena Hyeana brunnea and the spotted hyaena Crocuta crocuta in the southern Kalahari. Koedoe (Suppl) 27:237-247.

Mills MGL., Funston PJ. 2003. Large carnivores and savanna heterogeneity. In: Du Toit JT., Rogers KH., Biggs CH. eds. The Kruger experience. Ecology and management of savanna heterogeneity. Washington DC: Island Press.

Mills MGL, Hofer H. 1998. Hyaenas. Status survey and conservation action plan. Gland, Switzerland and Cambridge, UK: IUCN/SSC Hyaena Specialist Group.

Mohr CO. 1947. Table of equivalent populations of North American small mammals. American Midland Naturalist 37:223-249. DOI:10.1371/journal.pone.0100764. 

range, activity and sociality of a top predator, the dingo: a test of the Resource Dispersion Hypothesis. Ecography 36:914-925. DOI: 10.1111/j.16000587.2013.00056.x.

\section{Newsome TM., Ballard GA., Fleming PJS., Ven R van de., Story GL., Dickman CR.} 2014. Human-resource subsidies alter the dietary preferences of a mammalian top predator. Oecologia 175:139-150. DOI: 10.1007/s00442-014-2889-7.

Ogutu JO., Owen-Smith N. 2003. ENSO, rainfall and temperature influences on extreme population declines among African savanna ungulates. Ecology Letters 6:412-419. DOI 10.1046/j.1461-0248.2003.00447.x.

\section{Ordeñana MA., Crooks KR., Boydston EE., Fisher RN., Lyren LM., Siudyla S., Haas} CD., Harris S., Hathaway SA., Turschak GM., Miles AK., Van Vuren DH. 2010. Effects of urbanization on carnivore species distribution and richness. Journal of Mammalogy 91:1322-1331. DOI: 10.1644/09-MAMM-A-312.1.

Owen-Smith N. 1990. Demography of a large herbivore, the greater kudu Tragelaphus strepsiceros, in relation to rainfall. Journal of Animal Ecology 59:893-913. DOI: $10.2307 / 5021$.

Payne LX., Schindler DE., Parrish JK., Temple SA. 2005. Quantifying spatial pattern with evenness indices. Ecological Applications 15:507-520. DOI: 10.1890/03-5029.

Pereira LM., Owen-Smith N., Moleón M. 2013. Facultative predation and scavenging by mammalian carnivores: seasonal, regional and intra-guild comparisons. Mammal Review 44:1-12. DOI: 10.1111/mam.12005.

Quinn JH., Whisson DA. 2005. The effects of anthropogenic food on the spatial behaviour of small Indian mongooses (Herpestes javanicus) in a subtropical rainforest. Journal of Zoology 267:339-350. DOI: 10.1017/S0952836905007491. 
Redfern JV., Grant R., Biggs H., Getz WM. 2003. Surface-water constraints on herbivore foraging in the Kruger National Park, South Africa. Ecology 84:1092-2107. DOI:10.1890/01-0625

Riley SP., Boydston EE., Crooks KR., Lyren LM. 2010. Bobcats (Lynx rufus). In: Gerht S., Riley SP., Cypher BL eds. Urban carnivores: ecology, conflict and conservation. Baltimore: John Hopkins University press, 121-140.

Row JR., Blouin-Demers G. 2006. Kernels are not accurate home range size estimators for herpetofauna. Copeia 4:797-802. DOI: 10.1643/0045-8511.

\section{Rutherford MC., Mucina L., Lötter MC., Bredenkamp GJ., Smit JHL., Scott-Whaw} RC., Hoare DB., Goodman PS., Bezuidenhoit H., Scott L., Ellis F., Powrie LW., Siebert F., Mostert TH., Henning BJ., Venter CE., Camp KGT., Siebert SJ., Mathwes WS., Burrows JE., Bodson L., van Rooyen N., Schmidt E., Winter PJD., du Preez PJ., Ward RA., Williamson S., Hurter PJH. 2006. Savanna biome. In: Mucina L., Rutherford MC eds. The vegetation of South Africa, Lesotho and Swaziland. Strelitza 19. Pretoria: South Africa National Biodiversity Institute, 438-539.

Ryan B. 2007. Effects of anthropogenic food sources on diet and parasite loads in spotted hyaena, Crocuta crocuta (Erxleben, 1777) in Kruger National Park,. MSc. Thesis. Pretoria: University of Pretoria.

Šálek M., Drahníková L., Tkadlec E. 2015. Changes in home range sizes and population densities of carnivore species along the natural to urban habitat gradient. Mammal Review 45:1-14. DOI: 10.1111/mam.12027.

Sandell M.1989. The mating tactics and spacing patterns of solitary carnivores. In: Gittleman JL ed. Carnivore behavior, ecology, and evolution, Ithaca: Cornell University Press, $164-182$

Samuel MD., Pierce DJ., Garton EO. 1985. Identifying areas of concentrated use within a 
home range. Journal of Animal Ecology 54:711-719. DOI: 10.2307/4373.

Schuette P., Wagner AP., Wagner ME., Creel S. 2013. Occupancy patterns and niche partitioning within a diverse carnivore community exposed to anthropogenic pressures. Biological Conservation 158:301-312. DOI: 10.1016/j.biocon.2012.08.008.

\section{Seydack AH., Grant CC., Smit IP., Vermuelen WL., Baard J., Zambatis N. 2012. Large} herbivore population performance and climate in a South African semi-arid savanna. Koedoe 54:1049. DOI: 10.4102/koedoe.v54i1.1047.

Smit IPJ., Grant CC., Devereux BJ. 2007. Do artificial waterholes influence the way herbivores use the landscape? Herbivore distribution patterns around rivers and artificial surface water sources in a large African savanna park. Biological Conservation 136:8599. DOI: 10.1016/j.biocon.2006.11.009.

Swihart RK., Slade NA. 1985. Testing for independence of observations in animal movements. Ecology 66:1176-1184. DOI: 10.2307/1939170.

Venter FJ., Gertenbach WPD. 1986. A cursory review of the climate and vegetation of the Kruger National Park. Koedoe 29:139-148. DOI: 10.4102/koedoe.v29i1.526.

Venter FJ., Scholes RJ., Eckhardt HC. 2003. The abiotic template and its associated vegetation patterns. In: Du Toit JT., Rogers KH., Biggs HC. eds. The Kruger Experience: Ecology and Management of Savanna Heterogeneity. Washington DC, USA: Island Press, 83-129.

Woodroffe R. 2000. Predators and people: using human densities to interpret declines of large carnivores. Animal Conservation 3:165-173. DOI: 10.1111/j.14691795.2000.tb00241.x.

Yirga G., Leirs H., De Iongh HH., Asmelash T., Gebrehiwot K., Deckers J., Bauer H. 2015. Spotted hyena (Crocuta crocuta) concentrate around urban waste dumps across Tigray, northern Ethiopia. Wildlife Research 42:563. DOI: 10.1071/WR14228. 

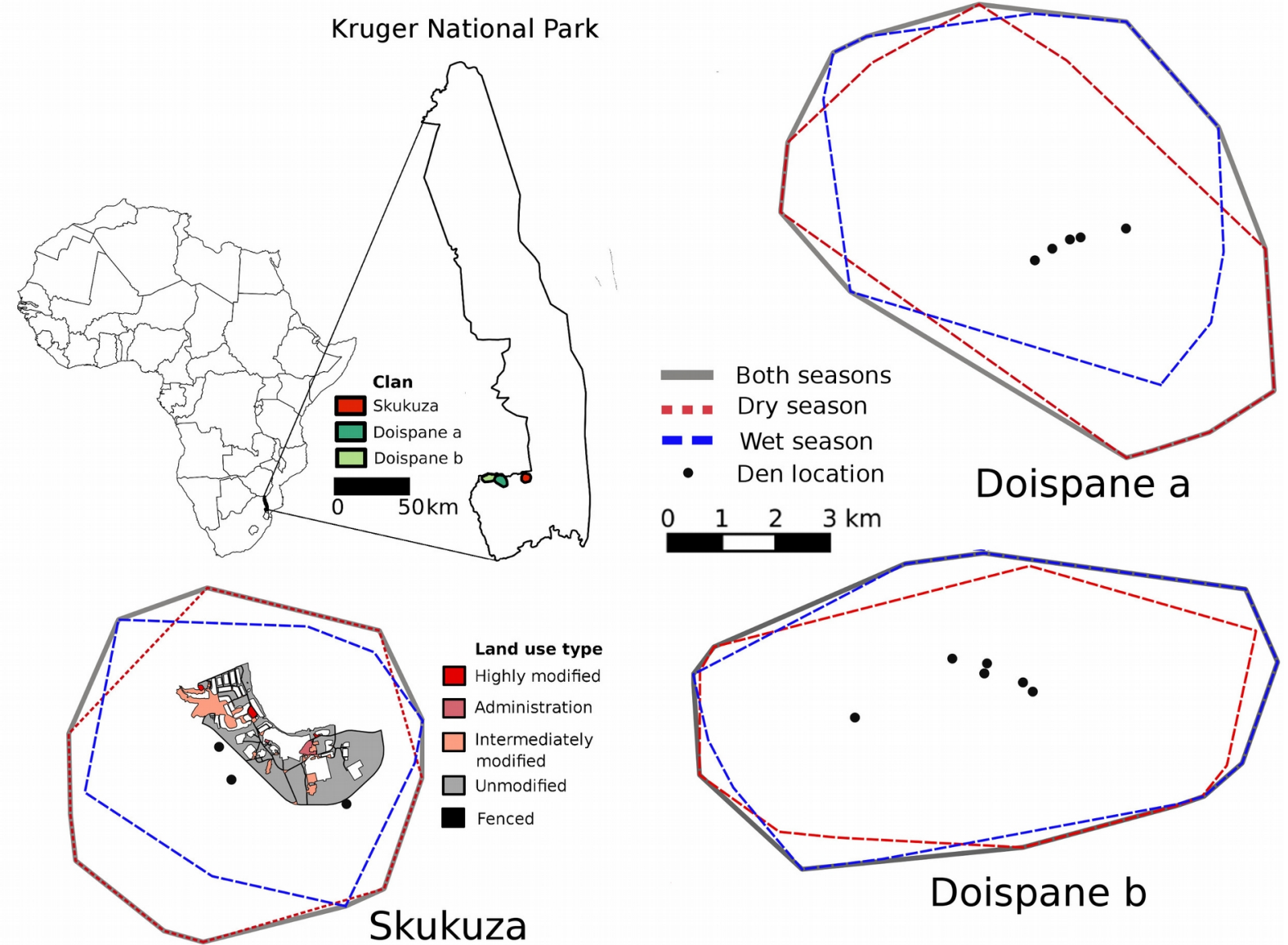

Figure 1 Locations of the three home ranges within the Kruger National Park as well as

637 village area with four unfenced land use types; highly modified, administration, intermediately modified and unmodified areas. 
639 Table 1: Sizes $\left(\mathrm{km}^{2}\right)$ of seasonal and annual home ranges (95 \% MCP) in three areas of

640 different levels of human activity. The low activity sites were inhabited by the same clan

641 that sequentially shifted their home range half way through the study.

\begin{tabular}{llll} 
Level of human activity & Annual & Dry season & Wet season \\
\hline High human activity & 33.7 & 31.6 & 24.5 \\
Low human activity (a) & 53.1 & 44.4 & 39.7 \\
Low human activity (b) & 47.9 & 41.0 & 45.6 \\
\hline
\end{tabular}


642 Table 2. Spatial distributions of spotted hyaena night and day locations in three home

643 ranges with contrasting levels of human activity. The low activity home ranges were

644 inhabited by the same clan that sequentially shifted their home range half way through the

645 study. The spatial distribution of active points were evaluated with using a normalized

646 Shannon spatial diversity index $\left(H^{\prime}\right)$, which range from 0 (completely clustered use of space)

647 to 1 (completely even use of space). The spatial distributions of resting sites were quantified

648 as a nearest neighbour index $(R)$, which ranges from 0 (totally clustered distribution) to 2.15

649 (completely even distribution). A value of 1 indicates a random distribution, values $>1$

650 indicates an overdispersed distribution and values $<1$ indicates a clustered distribution.

\begin{tabular}{|c|c|c|c|c|c|c|c|c|c|}
\hline \multirow[b]{2}{*}{ Home range } & \multirow[b]{2}{*}{ Human activity } & \multicolumn{4}{|c|}{ Night } & \multicolumn{4}{|l|}{ Day } \\
\hline & & $\boldsymbol{H}_{\text {Obs }}^{\prime}$ & $\boldsymbol{H}_{\text {Exp }}^{\prime}$ & $Z$ & $\boldsymbol{P}$ & $\boldsymbol{R}_{\text {Obs }}$ & $\boldsymbol{R}_{\text {Exp }}$ & $Z$ & $\boldsymbol{P}$ \\
\hline \multicolumn{10}{|l|}{$\underline{\text { Both seasons }}$} \\
\hline Skukuza & High & 0.69 & 0.85 & 40.3 & $<0.001$ & 0.41 & 1.03 & 16.2 & $<0.001$ \\
\hline Doispane a & Low & 0.71 & 0.84 & 14.4 & $<0.001$ & 0.44 & 1.04 & 10.4 & $<0.001$ \\
\hline Doispane b & Low & 0.65 & 0.77 & 27.6 & $<0.001$ & 0.39 & 1.03 & 15.2 & $<0.001$ \\
\hline
\end{tabular}

Dry season

$\begin{array}{llllllllll}\text { Skukuza } & \text { High } & 0.63 & 0.78 & 30.7 & <0.001 & 0.35 & 1.03 & 14.5 & <0.001 \\ \text { Doispane a } & \text { Low } & 0.71 & 0.91 & 12.1 & <0.001 & 0.52 & 1.06 & 6.88 & <0.001 \\ \text { Doispane b } & \text { Low } & 0.75 & 0.87 & 10.6 & <0.001 & 0.42 & 1.05 & 8.79 & <0.001\end{array}$

Wet season

\begin{tabular}{llllllllll} 
Skukuza & High & 0.69 & 0.85 & 18.8 & $<0.001$ & 0.52 & 1.04 & 7.96 & $<0.001$ \\
Doispane a & Low & 0.81 & 0.90 & 5.90 & $<0.001$ & 0.55 & 1.07 & 5.55 & $<0.001$ \\
Doispane b & Low & 0.70 & 0.81 & 16.9 & $<0.001$ & 0.39 & 1.04 & 11.9 & $<0.001$ \\
\hline
\end{tabular}


Table 3. Spotted hyaena utilization of a village area and of different land use types within this village area in the Kruger National Park.

Percent of locations for the non-village and the village area refer to the percent of all locations within the home range, whereas the percent of locations of each land use type refer to the percent of locations within the village area. Beta coefficients describes relative selection for the village area and within the village area also for the different land use types, scaled so that values $<0$ indicates avoidance (i.e. that an area is used less than its availability) and values $>0$ indicates preference (i.e. that an area is used more than its availability).

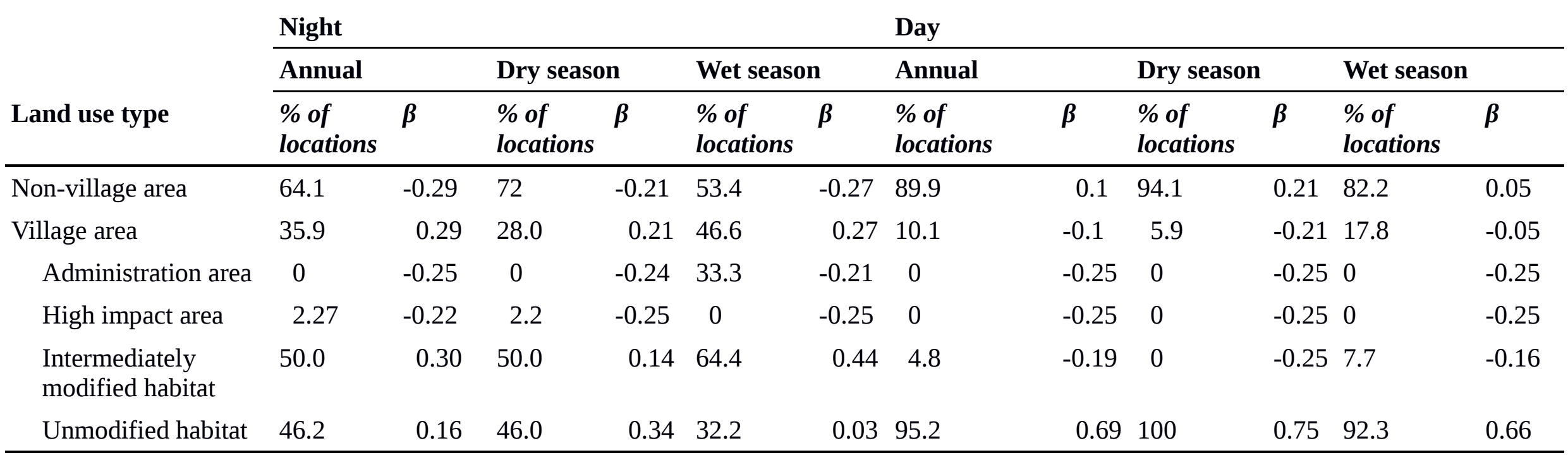

